\title{
Bad English and Fresh Spaniards Translation and Authority in Philippine and Cuban Travel Writing
}

\author{
_ Ernest Rafael Hartwell \\ College of the Holy Cross, Massachusetts
}

\begin{abstract}
Cuban José Martí narrated his 1880 travels in New York in "bad English” while Filipino Antonio Luna commented on his 1889 travels in Madrid in "fresh Spanish." The texts chronicle the shifting and wary gazes of colonial travelers toward Spain's waning imperial rule and the rise of US expansionism, travelers who employ imperial languages to express anti-imperial messages. Through the mechanisms of translation, Luna and Martí bolster their own authority within a hostile, metropolitan environment. By dictating the terms through which multiple languages engage with each other, Luna and Martí also dictate how different subjects engage with each other. This leads them to make vastly diverging claims about what it means to be a "savage" in the late 19th century.
\end{abstract}

\section{Keywords}

José Martí, Antonio Luna, Travel Chronicles, Anticolonial Writing, Translation, Authority, Racialization, New York, Madrid, 19th Century 


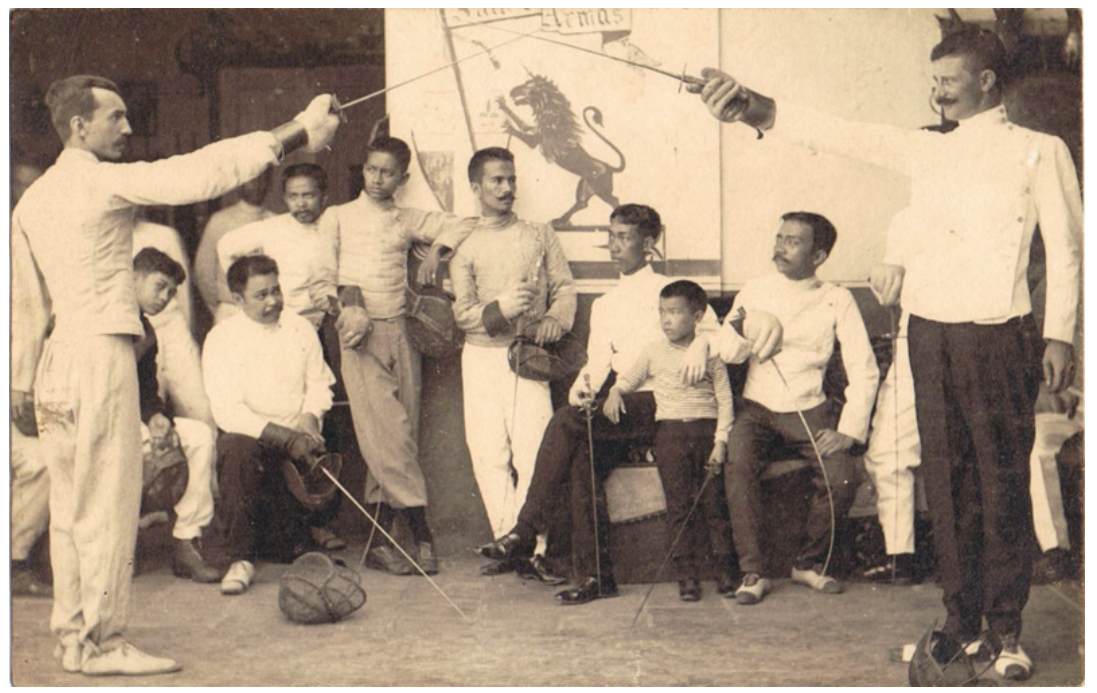

Fig. 1. Antonio Luna with Salas de Armas Students; https://commons.m.wikimedia.org/wiki/File:Antonio_ Luna_with_Sala_de_Armas_students.png

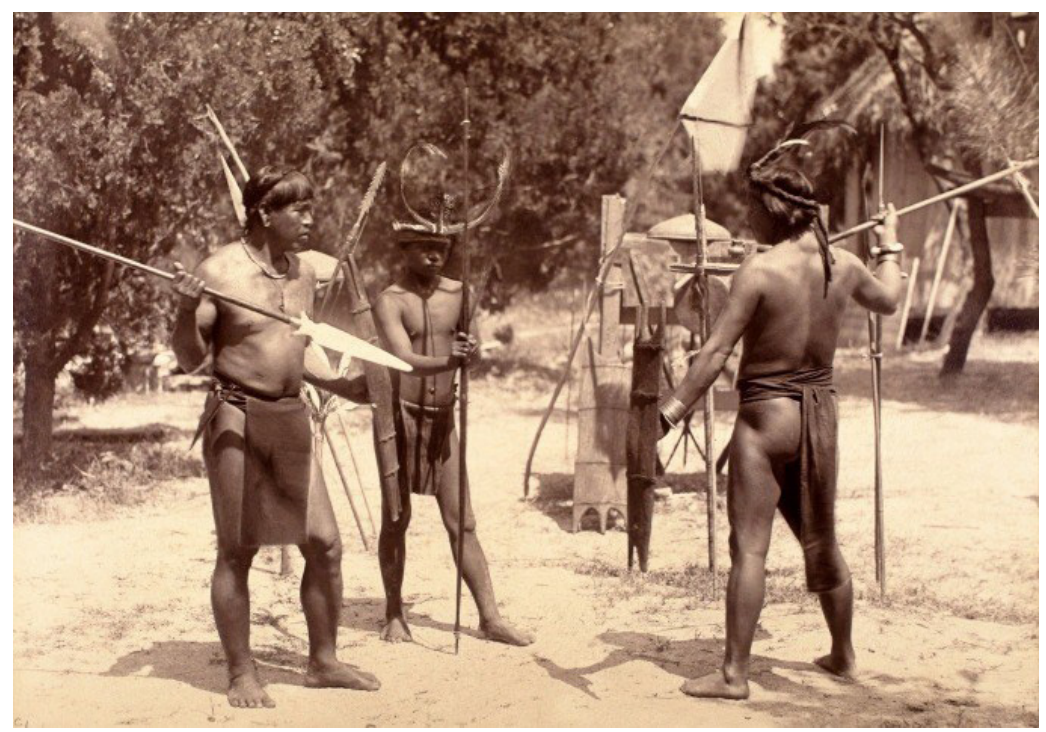

Fig. 2. Imágenes de una exposición. Filipinas en el parque del Retiro, en 1887; https://madridfree.com/imagenes-de-una-exposicion-filipinas-en-el -parque-del-retiro-en-1887/ 


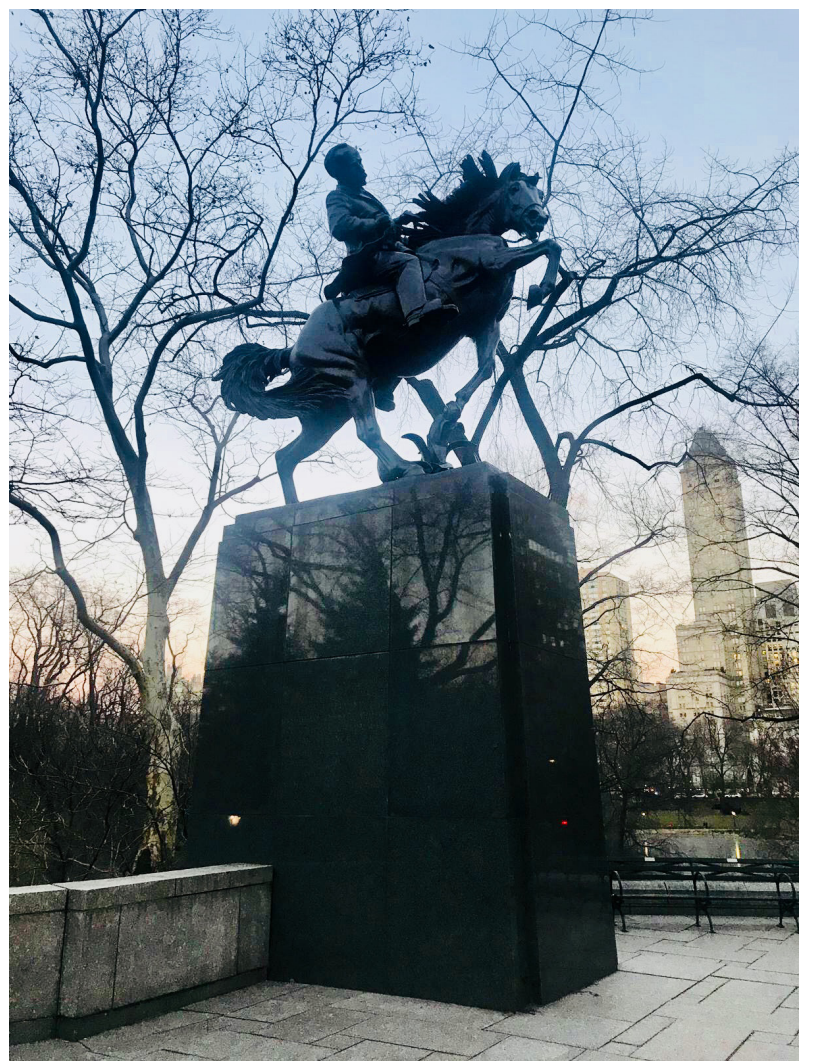

Fig. 3. Martí Monument in New York (๑ Patricio Orellana 2019) 


\section{Travel, Translation, Authority: An Introduction}

In October 1880, Cuban José Martí publishes a chronicle in The Hour, a New York art weekly, in which he comments on how New Yorkers speak English. Martí argues that unlike its British roots, US English is vague, incomprehensible, and lacks culture. He insists that he need not write well in English to note that northerners of the US speak English poorly.

In December 1889, Filipino Antonio Luna confronts a young Spanish girl in Madrid who is surprised that he can speak Spanish, as registered in his travel chronicle published in a Philippine fortnightly magazine, La Solidaridad. He informs her that Spanish is the official language of the Philippines while also correcting her vocabulary in her native tongue; the language they are speaking is not called "Spanish," but rather "Castilian."

These two scenes inspire a series of questions: What happens when an intellectual from a colony travels to a metropolis and writes about it? By what authority does such a writer say anything about the customs and cultures of those who dwell in imperial capitals? If the traveler does not appear to have such authority, can authority be constructed through the process of writing? What is the role of language, specifically imperial languages, in this struggle for intellectual and tangible power? The essay that follows takes these scenes and questions as invitations to address the dynamic relationship between translation and authority in Martís "badly written" English impressions about New York in dialogue with Luna's Spanish-language impressions about his travels in Madrid.

Nineteenth-century travelers from Latin America and the Philippines did not commonly write about the capitals they visited. Europeans traveled to and wrote about the Philippines and Latin America in great numbers in the 18th and 19th centuries. André Pierre Ledru of France, Alexander von Humboldt of Germany, and Ramón de la Sagra of Spain wrote extensive naturalist accounts about their travels in the Caribbean and throughout the Americas. Spaniards Antonio Chápuli y Navarro, Vicente Barrantes, Wenceslao Retana, and Pablo Feced y Temprado traveled to the Philippines about which they wrote a series of "costumbrista," ethnographic, and historiographical texts. These practices were central to the development of natu- 
ralism through which European scientists and writers pursued a subtle, yet impactful second wave of European conquest (Pratt 7). ${ }^{1}$

Wealthy Latin Americans and Filipinos traveled extensively to the US and Europe in the 19th century. Julio Ramos asserts that Latin American travelers often sought education and other tools they could use to order the supposed chaos back home (Ramos 146 and Rivera Nieves 51). Travelers were reluctant to write about Europe because expressing verbal claims about their experiences in the metropolis would, in Mary Louise Pratt's terms, "imply a reciprocity not in keeping with colonial hierarchies" (190). Very few of these travelers, outside of Argentine Domingo Faustino Sarmiento, dared to break with these hierarchies, until along came two writers from Spain's last remaining overseas colonies: Martí and Luna.

Martí's English chronicles are titled "Impressions of America by a very Fresh Spaniard," rather similar to the title of Luna's Spanish accounts: "Impresiones madrileñas de un filipino." These parallel texts employ imperial languages to articulate anti-imperial messages. The traveling writers stage power struggles within the very language of their chronicles. Instead of seeking tools in New York and Madrid to order the chaos back home, Martí and Luna use discursive tools from back home to order what they perceive to be confused in the cultural capitals of the falling and rising empires, Spain and the US.

In their chronicles, Luna and Martí craftily manipulate language, making it difficult to establish where writing stops and translation begins. Very little has been written about the work of translation as a strategy to bolster authority within a hostile environment in either Martí's or Luna's writings. For Martí, there have been structural analyses of his translations of Latin, French, and English works to Spanish by Leonel Antonio de la Cuesta and Lourdes Arencibia Rodríguez. Most influential for this essay is the work of Esther Allen, who asserts that translation is an epistemological process for Martí; like his translations, Martí's thought is "not abstract or ahistorical, but contextual, relational, derived from a unique conjunction of circumstance addressed in their specific particularity and from a singular and situationally rooted viewpoint" (30). This relational aspect corresponds with 
Vicente Rafael's reading of translation in Antonio Luna's writing, Rafael being the only scholar to examine Luna's language as a function of translation. Rafael asserts that Luna uses the Spanish language as a code to deliver insurgent messages to a non-Spanish readership; translation is a process of rendering something foreign. Rafael argues that through translation, Luna communicates covertly while also embodying "an excess of messages beyond his control" (Promise of the Foreign 34).

In this article, translation refers to this idea of Rafael's, which dialogues with Walter Benjamin's concept of "translatability." Translation is more than substituting the language of a text with another; it is a mode of expression that points to the interrelation between different languages, while also highlighting any one linguistic utterance's inevitable estrangement from itself over time. Rafael calls this quality "the promise of the foreign;" language is never static, always dynamic, and because of this ever-changing nature, any text's possibility for comprehension in the future is always rooted in translation (Promise of the Foreign 15).

Consequently, translation underlines the political nature of linguistic projects to preserve traditional language usage, as well as efforts to innovate with and diverge from traditional language rules. On the one hand, translation represents a reality of language; language constantly becomes foreign to itself, inspiring some to try and arrest that change and others to embrace it. $^{2}$ On the other hand, as examined in the pages that follow, translation represents a mode of assigning meaning to two languages' interactions with each other, as well as a manner of mediating and regulating the interactions between people who speak the different languages. By studying Martís and Luna's approaches to translation, one can decipher their interpretations of the colonial power dynamics and distributions of authority in the late 19 th century, dynamics and distributions which were perpetuated in large part through the language used by colonial authorities, imperial apologists, seekers of reform and autonomy, and proponents of revolution.

This brings us to the concept of authority, framed by Hannah Arendt's essay "What is authority?" and Jacques Rancière's concept of the "distribution of the sensible." On the one hand, Arendt asserts that authority speaks 
to a stable and necessarily hierarchical distribution of agency within a certain community, within which persuasion is impossible and coercion is unnecessary (2). Arendt's notion inspires one to ask the following questions, relevant to the study of Luna's and Martí's travel writings: in order to critique authoritarian forms of rule, must anti-colonial writers act in an authoritarian manner? Must they perpetuate some forms of hierarchy to critique other forms of it? Jacques Rancière dialogues with this idea with his concept of the "distribution of the sensible," which asserts that within a given community, the ability to sense, say, and do is finite, and therefore unevenly distributed among those who live in the community. This expounds upon Plato's idea that the peasant cannot participate in politics because he does not have enough time to do so. Rancière asserts that certain events-including technological advances, war, art, and literature-can intervene and in a sense "redistribute" the predetermined shares (from French "partage" which Rancière uses in the text's original language) of aesthetic capability and authority to say and do within a specific socio-political order or hierarchy (12). Martí's and Luna's impressions illustrate how translation promotes forms of redistributed authority within the still-colonized island regions and the rising and falling imperial capitals of the late 19th century.

In the following sections, I first touch on the historical context that binds and divides Martí and Luna. Then, I examine what Martí calls his "bad English” alongside Luna's insubordinate use of Spanish. Luna's and Martís uses of imperial languages represent forms of translation through which they smuggle insurgent messages to friendly and unsympathetic readers alike. Luna and Martí turn to a series of strategies of translation in order to authorize themselves from within the hostile communities in which they find themselves, to diagnose the ills of the empire, to destabilize hierarchies, and to propose and prescribe different forms of sociability. I argue that what appear to be errors in Martís English language writings are actually instances in which he aims to exert control over both the North American form of English and the North Americans, themselves. This control is framed in the form of a civilizing effort that is at the same time an effort to render North Americans and US English “wild.” Martís and Luna's approaches diverge in 
their interpretation of savagery. As explored in this essay's conclusion, these nuanced divergences highlight a decisive way in which race implicates itself in Martí's and Luna's writing, in the anticolonial politics of the moment, and in different cultural struggles that continue until today.

\section{History that Binds and Divides}

Puerto Rico, Cuba, and the Philippines are the islands that remained under Spanish rule long after nearly all other former Spanish colonies had achieved independence. The rich traditions of Philippine and Caribbean anticolonial writings coincided on several points including their demands for greater representation, less corruption, better education, and less censorship. The demands diverged with regards to the central issues they brought up, the abolition of slavery in the Caribbean and the removal of the friars in the Philippines (Fradera 77; Hagimoto 11; García 9).

For centuries, the Philippines had served Spain as a gateway to the East, a site where Asian spices and silk could be exchanged for Mexican gold. The country was not exploited agriculturally, which led to both its native populations and languages surviving, as opposed to those of the Caribbean. Likewise, the African slave trade did not dominate the Philippines as it had the Caribbean. ${ }^{3}$ In fact, Spain even sent relatively few administrators to the Philippines, and these remained in Manila. Spanish friars, however, learned local languages and spread throughout the archipelago, gaining an inordinate amount of power (Rafael, Promise of the Foreign 7). The intellectuals of the Philippines centrally protested the corruption of the friars who extorted their parishioners and sabotaged the education system (Schumacher 24). The friars limited Filipinos' verbal skills in Spanish; at the end of the 19th century, less than $10 \%$ of the country could understand Spanish (Rafael, Contracting Colonialism 56). The friars, thus, became the translators between the people and the government, always ensuring the permanence of their own power (Rafael, Promise of the Foreign 24-25). While in the Caribbean, rich and poor alike spoke Spanish; in the Philippines only the intellectuals of the late 19th century did. These Filipino "Ilustrados" wrote mostly in Spanish in order to collaborate with intellectuals from other Philippine language groups, to 
communicate with European sympathizers, and to undercut friar attempts at limiting their representative power within the colonial government.

Meanwhile, the Latin American wars of independence led Spain to prioritize their economic apparatus in Cuba and Puerto Rico, structured centrally around agriculture and slavery. This led to a dramatic increase in slave importation to the Caribbean. In response, Cuban and Puerto Rican intellectuals in large part pushed for the abolition of slavery, identifying the practice as archaic and economically limiting, but also fearing slave uprisings like those of Haiti (Schmidt-Nowara, Empire and Antislavery 4). In Cuba with the "Guerra de diez años" and the "Guerra chiquita" of the 1870's, this radical racial division embodied by both the institution of slavery and the movement of abolitionism, shifted in a slow and convoluted manner toward the collaboration of white liberals and enslaved and formerly enslaved black people against Spanish military forces (Ferrer 34). Spain responded to such anti-imperial projects by exiling a great number of Cubans. However, the expatriate communities of Key West and New York organized many of the efforts behind the revolutionary movements leading up to 1898 (Mañach 150-152).

Developments in transportation technology and the 1869 opening of the Suez Canal allowed for more and more Filipino, Cuban, and Puerto Rican youths to travel to and study in the US and Spain. ${ }^{4}$ In Spain, the writers sought education and also were subject to theatrical representations of their supposed inferiority. Burlesque representations of Afro-Caribbean and Philippine societies littered Spanish theaters and a Philippines exposition was set up in Madrid's Parque del Retiro in 1887, complete with imported water buffalos, transplanted khasi pines, freshly erected nipa huts, and loincloth-wearing Igorot people transported from the mountainous region of the north of the Philippines to Madrid (Sánchez Gómez 59). These spectacles promoted an orientalizing gaze through which imperial apologists could distort and invent the colonized subject, and in the process, the empire could define itself in opposition to this artificial other. Luna and Martí wrote within a cultural context in which imperial apologists constantly doubted the still-colonized peoples' sophistication and humanity. Menéndez Pelayo said 
that Puerto Ricans and Cubans "had no history" (Schmidt-Nowara, Conquest of History 120) and Wenceslao Retana said about Filipinos, "Why should it cause offense that I conceive of the Malay race as inferior to the European races? This is a purely scientific opinion..." (Schmidt-Nowara, Conquest of History 176). This underlines an important difference between Martí and Luna. Luna was visibly different from his Madrid "hosts;" his Malay appearance distracted interlocutors no matter how well he spoke Spanish. Martí, however, inherited a mostly white-presenting appearance from Cuban and Canary Islander parents who descended from Spaniards; the major marker of his difference in the US was his language.

\section{"Bad" English}

In 1868, at the age of 15, Martí joined the Yara rebellion and was imprisoned by the Spaniards. This led to many years of exile in Spain, Mexico, Guatemala, Venezuela, and the US where he spent the majority of his 25 years abroad (Kirk 276). He arrived in the US in 1880 and published an extensive series of poems, essays, and chronicles in Latin American newspapers and publishing houses (Rotker 13). Abroad, he also helped organize the Cuban independence movement, eventually returning to fight for his home island in 1895 where he was killed in combat (Schnirmajer 27 and Hagimoto 152).

In the same year that he moved to the US-1880-Martí published 20 articles in English in The Hour, a New York arts and social interests magazine. A polemic has arisen about the language in which the texts were written. The traditional narrative asserts that Martí wrote all of the articles in French, having the editors translate them to English. ${ }^{5}$ Corroborating this theory are the testimony of magazine editor Charles Dana (Rodríguez 9) and manuscripts in French for four of the twenty articles held at the Centro de Estudios Martianos in Havana. Martí biographer Jorge Mañach and translator Esther Allen suggest, however, that at least three of the texts that Martí published in The Hour were written originally in English. These are the three first-person travel chronicles entitled "Impressions of America by a Very Fresh Spaniard.” No French manuscripts exist for these three chronicles which are rife with grammatical errors, awkward phrasing, and invented 
words. Such linguistic idiosyncrasies are not present in Martís articles for which manuscripts in French exist. ${ }^{6}$

A closer look at these errors suggests both that the text was written originally in English and that the errors were not errors at all but rather purposeful and decisive aesthetic and political gestures. No scholars have pursued such an approach up until now, not even Mañach and Allen who take these errors to be idiosyncratic but not necessarily purposeful. A close reading of these apparent "errors" reveals that Martí's forms of "bad English" are not only indicative of his writing these three articles in English but also represent purposeful, stylistic decisions. The "errors" are distinct manifestations of the work of translation in Martí's English prose, and through them Martí authorizes himself to act as critic of the US's culture and as intervener in the US's language.

The title of Martí's chronicles, "Impressions of America by a Very Fresh Spaniard," is notable on several points. "Impressions," also used in the title of Antonio Luna's chronicles, points to the established school of European painting called "Impressionism" while also being widely used in the titles of costumbrista travel writing at the time, like Antonio Chápuli's Pepin: Impresiones-Viajes-Costumbres Filipinas. Both the literary and fine arts implications of the term "Impressions" indicate the prevalence of first-person perspective that differentiates "Impressions" from Martís other writings about the US where impersonal and disembodied bird's eye perspectives prevail. Martí's use of "America” in the title is also notable, given his impactful posterior writings on "Nuestra América." Calling himself a Spaniard in these English-language chronicles, furthermore, plays into his construction of a link between himself and classical culture via Spain, while also perhaps playfully appropriating the tendency of Anglo-Americans to call anyone who speaks Spanish "Spanish.” This also suggests that while Martí opposes both the continuation of Spanish colonial rule and the threat of US imperial expansion into Cuba, he deems the latter to be a greater threat on both a geopolitical and cultural level. Finally, the term "fresh" has been a source of controversy. In subsequent collections, it has been translated as "muy fresco" and "recién llegado," different translators arguing about which connotation 
was most important with the term-the impertinence of "fresh" or the fact that Martí had just arrived in the US in $1880 .^{8}$

As suggested by the title, "Impressions" employs first-person narrations that intervene in fascinated and critical descriptions of North Americans:

At a first glance what else can I tell? I have all my impressions vividly awaken. The crowds of Broadway; the quietness of the evenings; the character of men; the most curious and noteworthy character of women; the life in the hotel, that will never be understood for us; that young lady, physically and mentally stronger than the young man who courts her; that old gentleman, full of wisdom and capacity who writes in a sobrious language for a hundred newspapers; this feverish life; this astonishing movement; this splendid sick people, in one side wonderfully extended, in other side-that of intellectual pleasures-childish and poor; this colossal giant, candorous and credulous; these women, too richly dressed to be happy; these men, too devoted to business of pocket, with remarkable neglectness of the spiritual business,all is, at the same time, coming to my lips, and begging to be prepared in this brief account of my impressions (34-35).

The clipped pace and prevalence of semi-colons graphically echo an anxiety before the rhythm of life and the crises in cultural order and gender roles in North America. These moments of ambivalence before the scenes of industrial progress in the US are seminal in a more general move in Martí's intellectual writings, in which he equates the technological sophistication of the US with the death of culture. Within this framework, New York is a near perfect foil to the technologically tardy, yet culturally rich cities of Latin America. ${ }^{9}$ Curiously, in "Impressions," Martí characterizes himself not as Cuban but as a Spaniard among the masses of European immigrants critiqued frequently in local newspapers for being "wild” and "indolent." Martí exclaims, "I said goodbye for ever to that lazy and poetical inutility of our European countries" (33). Through the phrase "poetical inutility," Martí assigns a value to a culture that he claims worries little about economic value or utility. This sets up a rivalry of values that his writing dramatically represents: the cult of poetic value and Europe versus the religion of economic value and the US. 
In the US, they cannot even speak right, especially in comparison to their culturally rich British counterparts. Martí describes the US form of speaking English as referenced on the opening page of this essay:

It is curious to observe that I can always understand an Englishman when he speaks to me; but among the Americans a word is a whisper; a sentence is an electric commotion. And if somebody asks me how can I know if a language that I so badly write, is badly spoken, I will tell frankly that it is very frequent that critics speak about what they absolutely ignore. . . All conversation is here in a single word: no breathe, no pause; not a distinct sound. We see that we are in the land of railroads.

'That's all'-'did'nt'-'won't'-ain't'-'indeed'-'Nice weather'-'Very pleasant'-'Coney Island'-'Excursion' (39-40).

This excerpt represents a self-conscious authorization of badly written English to confront a form of English that Martí considers badly spoken. Translation is at play on two interrelated levels.

First, there is Martí's "bad English," these jarring errors that point to the inventions and approximations of novice language learners transitioning from one tongue to another: "for ever" in two words; the awkward prepositional phrase, "in other side”; "candorous;" "sobrious;" "neglectness." These are words that will not be found in the dictionary. Martí uses the word "breathe" instead of breath, punctuates the conjunction "didn't" strangely, and uses the verb "tell" in place of "say," a frequent verbal behavior of new English learners. These moments lead scholars like Mañach and Allen to suggest that "Impressions" was written in English by a "Spaniard" so "Fresh" that he resorts to invented, awkward language to express himself.

Secondly, Martís critique of English in the US is rooted in translation as a "promise of the foreign." Martí considers US English as a language that has lost culture over time. It has become foreign to itself and, specifically, to its culturally rich British roots. Such a consideration reflects by synecdoche Martís interpretation of the potential effect of US industrialism on the Western Hemisphere. By disseminating the cult of industriousness and 
economic growth, the US destroys the "culture" and "sensuousness" of any and all who follow suit.

Martî's errors represent, as I will expound upon in the following pages, a form of translation that responds to and attempts to impede this impending crisis of culture, not just in the US, but potentially throughout the Americas, given the US's imperial potential. Antonio Luna's “Impresiones madrileñas de un filipino," which I touch upon in the following section, casts light on Marti's methods for using translation to muster the authority necessary to impede the spread of the US cult of industriousness. Luna's language of miseducation, present throughout his "Impresiones," suggests that translation can function to authorize outsiders to engage in and attempt to transform a group that they are not allowed to join.

\section{The Language of Miseducation}

In the Philippines, Antonio Luna was also imprisoned in connection with an armed rebellion, just a year before leaving for Europe in 1886. In Manila, Luna studied chemistry and literature at the Ateneo Municipal and at the Universidad de Santo Tomás. At the Universidad de Barcelona, he acquired his "licenciatura" in pharmacology and then his doctorate at the Universidad Central de Madrid where Martí had studied a decade before. In Spain, Antonio Luna published cultural commentary and travel chronicles under the pseudonym "Taga-Ilog," while being overshadowed by his brother, the painter Juan Luna, who won several European prizes in the 1880 s (Constantino 223). Like Martí, Antonio Luna also returned to his homeland to fight in the revolution. He had great success as a general, and occupies a privileged place in popular memory embodied in the 2015 feature action film, "Heneral Luna."10 Luna also died in war, having been assassinated in 1899 by fellow Filipino soldiers as a result of a complex power struggle with rival military leaders (José 377).

Preceding Luna's bellicose struggles are a series of everyday struggles that the Filipino traveler experienced in day-to-day life in Madrid, registered in his October 31, 1889 chronicle published in La Solidaridad, a Philippine magazine out of Barcelona. Luna narrates his struggle and disappointment: 
Mi tipo, pronunciadamente malayo, que habia llamado extraordinariamente la atención en Barcelona, excita de una manera notoria la curiosidad de los hijos de Madrid. Hay chula, señorita o modista que vuelve dos y tres veces la cara para mirarme y pronunciar con voz suficiente para ser oída:

-Jesús, iqué horroroso!

-iEs un chino!

- Es un igorrote!

(Para estos, chinos, igorrotes y filipinos son lo mismo.)

Chicos y grandes, chulos y no chulos, no contentos con esto, se ponen a vociferar como salvajes:

-jChino!

-iiChinitoo!!

-iiIgorrote!!

...Muchas veces al pensar en estas espontáneas manifestaciones, me pregunto si estoy en Marruecos, en las peligrosas comarcas del Rif, y hasta llego a dudar si vivo en la capital de una nación europea. (444-6)

[My very pronounced Malay figure which had extraordinarily attracted attention in Barcelona, excited in a flagrant way the curiosity of the children of Madrid. There are little girls and young women or modistes who turn their heads twice or thrice to look at me and to say, in a voice loud enough to be heard:

-Jesus! How frightening!

- He is Chinese.

-He is an Igorot.

(To these people Chinese, Igorots and Filipinos are one and the same.)

Small boys and big boys, ruffians and not ruffians, not content with this, started to shout like savages:

-Chinese!

-Chi-i-ne-ese!

-Igorot!

...Often in thinking about these spontaneous manifestations, I ask myself if I were in Morocco, in the dangerous borders of the Riffs and not living in the capital of a European nation] (Translation by Fores-Ganzon 445-7)

Luna responds to prejudice by displacing the streets of Madrid to the Rif, the region of Northern Morocco, in which Spain's two "autonomous cities" of Cueta and Melilla are situated, cities occupied by Spain since the 15th and 16 th centuries. In this region, frequent battles occurred between the Spanish and Berbers in the 1880s (Chandler 301). 
By comparing Spaniards with the Africans they subjugated and looked down on, Luna implies that the Spaniards themselves are the "savages." Undoubtedly problematic, Luna inscribes himself into a tradition of Northern Europeans who claimed that Africa began at the Pyrenees, critiquing racist Spanish by perpetuating racist equivalences between the categories of "African" and "savage." Through this complex repurposing of orientalism, Luna authorizes himself to stare back at those who ogled him in the Madrid streets. Likewise, Luna mirrors the ethnographic gaze by which Spaniards had justified their imperial permanence through the 1887 "Exposición filipina de Madrid."

Language is central both to this discriminatory imperial logic and to Luna's response to it. Spanish president Emilio Castelar falsely proclaimed that Filipinos of the late 19th century were anachronisms, "human species that reveal to us prehistoric times and examples of monosyllabic languages" (Schmidt-Nowara, Conquest of History 169). Not only is no Philippine language monosyllabic, but also Luna shows himself to be a polyglot who uses language dexterity as a tool of authorizing his anticolonial message. Take note of Spanish women's reactions to his speech, as seen in "Sangre torera" or "Bull-fighters blood," a chronicle published on December 15, 1889:

Estas niñas a veces nos creen chinos; ellas también ignoran qué es Filipinas y qué son los filipinos... Por eso se inician diálogos como éste:

-Pero qué bien habla usted el español.

-El castellano dirá usted, señorita.

-Sí, señor. Me extraña que usted lo posea tanto como yo.

-Es nuestro idioma oficial en Filipinas, y por eso lo conocemos.

-Pero, ipor Dios! ¿en su país de usted se habla el español?

-Sí, señorita.

一iiiAhhh!!!

Y en aquel jahhh! tan largo, dudoso o expresivo, iba envuelta toda la opinión formada por aquella madrileña de catorce o quince años.

Tal vez nos creía poco menos que salvajes o igorrotes; tal vez ignoraba que podíamos comunicarnos en el mismo idioma, que éramos también españoles, que debíamos tener los mismos privilegios y los mismos derechos, ya que teníamos los mismos deberes. (520-2) 
[These girls at times also think of us as Chinese; they also do not know what the Philippines is and who the Filipinos are...

Thus we hear dialogues like the following:

-But, how well you speak Spanish.

-Castilian, you mean, madam.

-Yes, sir. I am surprised that you speak it as much as I do.

-It is our official language in the Philippines and this is why we know it.

-But, goodness gracious! In your country, is Spanish spoken?

-Yes, madam

-Ahhh!!!

And in that long “Ahhh!!!” suspicious and expressive, would be wrapped all the opinion formed by that Madrid girl of fourteen or fifteen years.

Perhaps we are thought of to be little less than savages or Igorots; perhaps they forget that we can talk in the same language, that we are also Spaniards, that we should have the same privileges and rights inasmuch as we have the same duties.] (Translation by Fores-Ganzon 521-3).

In response to the young woman's shock at his linguistic ability, Luna corrects and instructs her. He replaces her use of the term "Spanish" with a more precise term, "Castilian," proceeding to a brief history lesson on Spanish imperialism. Luna's command of Castilian forms the basis of his claim to be Spanish and to have the same rights as Spaniards. He asserts that his mastery of multiple codes challenges his implicit position on a low rung of the imperial hierarchy. His gesture of translation as correction asserts that he is more familiar with codes of conduct and propriety than the young Spanish woman.

The fact that she is a young woman points to another issue of his intervention in structures of authority; he challenges racial and national hierarchies, while remaining notably uncritical of disparities in the distribution of agency between different genders. In fact, his authority over this young Spanish woman is not just an invitation to pedantically explicate colonial dynamics and linguistics to his juvenile interlocutor. ${ }^{11}$ Furthermore, it allows him to understand her entire essence, enough to translate even her inscrutable interjections like "ahhh," for his readers. Through such translations, Luna situates himself above both his female interlocutor and his readers, who otherwise could not have interpreted her interjections with such 
perspicacity. In order to undermine one form of authority, the racial hierarchy of empire, Luna acts in an authoritarian way by reinforcing gendered hierarchies. ${ }^{12}$

This recourse to divisive education recalls the central complaint of Filipino "ilustrados" that friars miseducated Filipinos and thus preserved for themselves a privileged position within the circulation of power in the colony. In his October 31, 1889 chronicle "Impresiones madrileñas de un filipino," Luna returns the gesture of miseducation to its source in a dramatized interaction with a Spanish ordained minister:

- ¿De dónde son $V d s ?$ ? preguntaba un presbitero.

-De Filipinas, cerca de China, provincia de Japón, al Norte de la Siberia.

- ¡Ajá! Yo tengo un hermano allá por... Mindanajao o Mindanajo. ¿Está eso por Luzón?

-Ya lo creo-continuamos seriamente; -de Manila, en dos horas en coche, y por el río Pasig, en seis horas en banca, llega usted a Mindanaw. (446)

[-From where are you?, asked a priest.

-From the Philippines, near China, province of Japan, north of Siberia.

-Aha! I have a brother there in... Mandanajao or Mindanajo. Is that in Luzón?

-Sure- and we would continue seriously, - two hours from Manila and six hours by banca on the Pasig River and you will be in Mindanao.] (Translation by Fores-Ganzon 447) ${ }^{13}$

He purposefully disorients the priest, twice rearranging the map of East Asia. Luna's discursive dexterity lies not only in manipulating the Philippines' geography and in disorienting one priest about the location of another priest in the Philippines, but also in the concrete language lesson he provides the minister. Luna corrects his pronunciation of Mindanao using "recast," a second language acquisition strategy of error correction, and provides him with particular Tagalog vocabulary, "banca," which has since been incorporated into Spanish, defined by the Real Academia as a "small embarkation used in the Philippines.”

By not translating "banca" to Spanish "bote" or "lancha," Luna doesn't teach vocabulary as much as he underlines its inaccessibility. Even his pseud- 
onym, under which Luna publishes these articles, "Taga-Ilog," is a bilingual joke left untranslated. It suggests the language "Tagalog," while meaning "from the river" in Tagalog. This reference to being from the river, points to two not mutually exclusive interpretations. First, Luna was from the Manila neighborhood of Binondo which is situated across the Pasig River from Intramuros, the sector of the city in which most of the Spanish in the Philippines resided. Binondo was founded in the early colony as a residence for Chinese Catholics, away from the center, but close enough to keep under their watch. The residents of Binondo were allies of the Spanish who were nonetheless objects of the Spaniards' suspicion. The other interpretation is that Luna christens himself using the figure of the river, an archetype of time and change, identifying himself, his writing, and his people, the Tagalog people, as harbingers of progress and change.

These jokes and insinuations, just like the word "banca" and the recast of the pronunciation of "Mindanao," were lost on his Spanish readers. ${ }^{14}$ They are residues of a language that Luna dominates and that Spaniards do not, marking what Doris Sommer would call a "slap of refused intimacy... slowing readers down, detaining them at the boundary between contact and conquest" (ix). Luna shows that not only does he fully know the language, history, and identity of his Spanish counterparts but also that they could never fully know him. He uses the Spaniards' language to authorize himself and exclude them. And with "banca," by maintaining a Tagalog word in his text, Luna inverts a process Vicente Rafael categorizes as the "missionary logic of translation based on untranslatability" (105). The missionaries converted Filipinos to Catholicism using the local tongues, keeping key words in Spanish and Latin and thus infusing them with primacy, sanctity, and power. Luna appropriates this strategy, assigning primacy to Tagalog by maintaining vestiges of it in his Spanish text.

Luna's contentious engagement with Spanish grants us a new framework with which to think about Martís writings in English. Luna's text shows that translation can be a mode through which travelers, immigrants, and other groups of outsiders authorize themselves to engage in and attempt to transform or correct a hegemonic group that they are not allowed to join. 
Both Luna and Martí are rejected from the communities they interact with. ${ }^{15}$ In turn, Luna and Martí engage in those communities in the communities' tongue, infusing their codes with dangerous difference. Through this form of translation they exert control over the interrelation of two languages, authorizing themselves to similarly prescribe correct means for the speakers of those two languages to interact. By exerting control over the hegemonic group's language, they transform a code of exclusion into a method for authorization to correct the supposed cultural superior, thus recalibrating the terms through which it is determined who can sense, speak, and do within such a community.

\section{Wild and Cultured}

In the above section on Martí's "bad” English, it becomes clear that the linguistic idiosyncrasies in "Impressions" noted by scholars such as Mañach and Allen were not errors but purposeful markers of two forms of translation. These two forms are, on the one hand, poetically devoid language as a marker of lost culture in the US and, on the other, Martí's linguistically and culturally rich response to such a crisis. Luna's tense interactions with residents of Madrid helped to illustrate that, with Martí too, translation of this latter kind allows outsiders to engage in and transform, on both the linguistic and interpersonal levels, certain hegemonic communities that exclude them. The following section goes more in depth about how Martí's linguistic games underline his poetic and political projects of intervening in the US English language, as well as asserting his authority to critique North American culture and politics and to forge a new "American" community through poetry and cultural resistance.

The key to Martís intervention in US English is encrypted in his comment in "Impressions" on how the US breaks immigrants in through integrating them into its economic apparatus. He exclaims with a hint of irony, "How great a nation must be, to conduct in a quiet way, these bands of wolves, hungry and thirsty, these excrescences of old poor countries, ferocious and unuseful there-and here, under the influence of work, good, kind and tame!" (35). This phrase portrays a forced transformation of wild and 
threatening European subjects, with whom Martí identifies, into productive and docile citizens. The language politics of this chronicle extrapolates upon the threat of European cultural intervention in the US, redirecting the logic of transformation of the quote. Martí associates Europe's "wildness" with its "poetical inutility" and its "culture." Through his linguistic idiosyncrasies which critics take as errors, Martí experiments with forms of authorizing himself and immigrants in the US in general through translation; translation, as in speaking English foreignly, allows the foreigner the ability to transform the country he or she arrives in, as opposed to being transformed by it. Therefore, while the US attempts to transform wild European immigrants into useful and tame citizens, Martí attempts to render "wild" and "cultured" the US version of the English language, which is tame, functional, and lacking in poetical value.

This "wilding" of a previously tame tongue occurs throughout the chronicles, even in the two previously included passages-Martís "first glance" of New York and his critique of how North Americans speak English. ${ }^{16}$ In these passages and throughout "Impressions," unlike his other English-language writings in The Hour which appear to be translated by someone else, Martí plays with the English language with creativity and irreverence, wielding homophones, neologisms, and oxymorons with great savvy. See the phrase, "... these women, too richly dressed to be happy; these men, too devoted to business of pocket." With homophones ("too" and "to"), he creates internal rhythm. He coins new adjectives like "sobrious" and "candorous" to plant internal rhyme into a culturally devoid landscape. Through the clause, "with remarkable neglectness of the spiritual business," Martí explores paradoxes like "spiritual business" and experiments with cultured neologisms, such as "neglectness." In this way, he injects poetic energy into spaces, like "business," where it previously was not.

With a sentence from his first paragraph- "Material power, as that of Carthage, if it rapidly increases, rapidly falls down" (33)-Martí illustrates the rise and fall of material power through parallel, metered verses. Such a tendency to versify prose appears throughout the three chronicles, signaled often through an excessive use of commas to create rhythmic breaks in 
the narration, breaks that make room for culture to infiltrate what Martí represents as a city that lacks culture. However, with Martí's reflection on Carthage, he appears to take this cultural infiltration by versification to a new level. In fact, if each comma indicated a versified pause, traditional Spanish scansion, including the rules of "sinalefa" and "diéresis" considered alongside US English pronunciation, would reveal a series of metered verses.

$$
\begin{aligned}
& \mathrm{Ma}(1)-\text { te }(2)-\mathrm{ri}(3)-\mathrm{al}(4)-\mathrm{pow}(5)-\mathrm{er}(6), \\
& \text { As }(1)-\text { that }(2)-\mathrm{of}(3)-\underline{\mathrm{Car}}(4)-\text { thage }(5), \\
& \text { If }(1)-\mathrm{it}(2)-\mathrm{ra}(3)-\text { pid }(4)-\text { ly-in }(5)-\underline{\text { crea }}(6)-\text { ses }(7), \\
& \mathrm{Ra}(1)-\text { pid }(2)-\mathrm{ly}(3)-\text { falls }(4)-\underline{\text { down }}(5+1)(6)
\end{aligned}
$$

First a hexasyllabic verse, followed by a pentasyllable, a heptasyllable and another hexasyllable. This parallel bilingual poetics provides a certain solemnity to the aphorismic judgment, which compares the US to a once great, now fallen civilization. Martí contrasts the scenes of low culture with a verse that is almost alexandrian in form. An alexandrian verse consists of two heptasyllabic hemistichs, as with Rubén Darío’s famous verse "La princesa está triste, ¿qué tendrá la princesa?” The alexandrian verse represents a style of high culture, "verso mayor," that poets like Martí and Darío adapt from the Parnassian school of French poetry, one of the key meters they introduce through the movement of Latin American modernismo (Onís 165). ${ }^{17}$

The fact that the versified prose is almost alexandrian represents a breach that could be interpreted as a fatal lack of culture or as the potential to acculturate. This brings up a tension in Martí's English-language writing. Martí confronts scenes of compromised humanity through the language he uses to describe them. ${ }^{18}$ But, through his infusion of culture in the US English language, is Martí humanizing the US with the tool of poetry, or is he subjecting the US to his discursive will? Is this an opening for reconciliation or a marker of decisive break? The resolution to this question only becomes clearer in subsequent writings of Martí like "Coney Island," "El puente de Brooklyn," and "Nuestra América," which reveal one of the most intriguing details about these "Impressions": they conjure an image of a Martí who has 
not yet made up his mind. His projects of poetic and political constructions appear to be taking form in these three brief chronicles but remain nebulous and undefined.

What is clear, however, is that whether he embellishes English to save it or to destroy it, he certainly undermines US notions of progress and modernity, doing so by marrying the concepts of the "wild" and "cultural sophistication" always against the forces of an encroaching US modernity. By embellishing and/or combatting the American English language with "European culture," Martí begins to sketch proximity between high culture and destructive nature, a proximity he continues to develop in nearly all of his later writings. ${ }^{19}$ "Wildness" is destructive in that it disrupts US notions of progress, preserving a space for culture. Culture is the measure of modernity, Martí insists, as opposed to the technological and economic drive that he witnesses, both fascinated and wary, in the US.

Although culture is destructive in that it undermines the US cult of industriousness, it also demands the restoration of previous social orders, chiefly underlined in Martí's "Impressions" as a rigorously gendered social order which is anything but chaotic. Martí repeatedly notes that in New York, men have forgotten that they should be manly and women, sensuous, a claim of deep resonance with the explicit and implicit gender constructions of Antonio Luna's chronicles. This even leads him to proclaim that, while in all countries of the world that he has visited, Martí has immediately fallen in love with at least one young woman; in the US he finds no one to love. They are simply not womanly like the women of his poetically inutile and culturally rich homeland. While reestablishing the prominence of culture within language, Martí also aims to fortify certain gender norms that he finds essential to these notions of culture, gender norms upheld in Latin America and in the South of the US, but at constant crisis in the North.

While Martí appears to articulate these embryonic reflections on an alternative modernity-rooted in culture, poetry, sensuous women, and manly men-in radical opposition to the US, his use of English tells a slightly different story. He says that despite the fact that he "badly writes" in English, he can still identify when it is "badly spoken," but his versified prose reveals 
that it is specifically because he badly writes that he has the authority to identify bad speech, and the corrupted culture it reveals. These are different notions of "bad" at play, however, revealing diverging notions of modernity. Martí's "bad" writing is fresh, irreverent, poetic, and wild, while the North Americans' "bad" speech is barren, efficient, indistinct, and lifeless.

His use of English is a form of contentious translation that, on the one hand, represents a resistance to being corrected and, on the other, leaves open the possibility of Martí paradoxically correcting his North American interlocutors through his "errors." He threatens to contaminate them with culture. These English-language chronicles diverge from Martís writings in Spanish in large part because they do not fully call for a break from the US. They do not prescribe radical opposition to the US forms of culture but rather represent an attempt to infuse the US with culture; Martí is an immigrant who refuses to be transformed, attempting rather to transform the language and country that fascinate and disturb him. The interplay between different languages of these brief travel impressions reveals them to be less a direct battle cry and more a threat of combative cohabitation. This form of constant translation is analogous in some ways to the tactics of guerrilla aggression; however, the combatant takes not to the hills, but hides his hostility within the language of his opponent.

\section{Conclusion}

In conclusion, through translation, Martí and Luna bolster their own authority within a hostile environment. A key takeaway from this study is that not all translations are the same. While all language is inherently translatable, that is, its comprehension in the future is dependent on the mechanisms of translation since language is constantly changing, different instances of translation can have dramatically different repercussions. Take for example Martís writings in The Hour that were translated from the initial drafts he wrote in French, like "The Nude in the Salon," which diverge from the affect fostered through the reading of "Impressions." "The Nude in the Salon" enlightens and pleases, while "Impressions" agitates while it entertains. Likewise, a native speaker's translation of a foreign text to his or her 
native tongue functions in a radically different way to the type of translation that occurs when a foreigner or immigrant decides to write in a foreign tongue.

Differences remain even between the outwardly similar projects of translation put forth by Martí and Luna. Most notably, they both call themselves "Spanish" in these chronicles, but for dramatically different reasons. Martís identification with Spain is rooted in his claim of difference from the United States, his claim for having deeper cultural roots. Luna, however, is still sincerely attracted to the idea of citizenship within a reformed Spain, an attraction rooted in his desire to transform what it means to be Spanish. Luna's proposal is paradoxical according to the logic of the time. He wants to make Spain less "savage" by making room within it for Filipinos, a desire he soon abandons when taking up arms against Spain and then against the US.

Luna's project to make Spain less "savage" points to another divergence in Luna's and Martí's projects of translation, namely in the effect race has in their interpretations of the category of the "savage." In two key essays of the 1890's, Martí pushes for a “Cuban race," not a black or white race, which is instrumental in consolidating the revolutionary movement in his home island (318). However, his refashioning of the "savage" in "Impressions," when analyzed alongside Luna's reticence to appropriate such a term, point to an important difference in their approaches to translation that is rooted in a persistent reminder of diverging implications of race in these authors' lives. Luna sees representations of his own supposed savagery on a day-to-day basis in Madrid. Therefore, he is reluctant to fuel the fire of these prejudices, even ironically. He would never dare to use "bad Spanish" or to call himself savage. He feels the need to constantly perform his intellectual capacity, in opposition to this supposed savagery. He claims the Spanish are the real savages, but does not directly problematize the logic behind that label. Martí, on the other hand, feels no such reluctance as he blends in with the crowds of New York. Martí is more willing to ironically appropriate the supposed wildness of immigrants and their language, especially when they are European immigrants. This is the root of his deconstruction of the category of the "savage" in which he aligns "savagery" with "culture." Savagery is not a category that 
directly or corporeally manifests itself in his life. But his willingness alongside Luna's reticence is an important reminder of the limitations of post-racial discourses that aim to reconcile racial differences and have the side effect of implicitly negating concrete disparities in the lived experiences of people of different races, both in the late 19th century and today.

Another key takeaway from this study is that what appear to be errors are not always errors, especially in the case of bilingual writers and activists. In light of this, Martís and Luna's exercises in translation and authority not only offer an insightful framework to think about travel writing, anti-colonial thought, and polemical linguistics in the late 19th century; they also engage in many of the same terms through which we have come to discuss Latino culture and linguistics, as well as Fil-am studies and other disciplines that examine diaspora. Luna's and Martís experiments in translation invite us to recognize how code-switching is not new and should not be identified as a deformation or a weakness, but as a recurrent historical process through which travelers, exiles, migrants, and refugees negotiate established hierarchies and rehearse new forms of sociability through the languages they speak and the grammatical or syntactical errors that they make. In sum, these impressions form a preemptive response to the people who might tell an immigrant in the US to "speak English," or any immigrant to speak the hegemonic language of the country where they reside. These chronicles "candourously" and "sobriously" invite the locals to be careful what they wish for. 
1. As Mary Louise Pratt argues, these scientific travelers and writers used their supposedly inoffensive gaze to affirm their non-engagement with imperialist violence while still aiming to possess what they gazed at and to assert and preserve European hegemony, even as the Spanish imperial power waned in the in the late 18th and 19th centuries (7).

2. For example, consider Antonio de Nebrija's Gramática de la lengua Castellana of 1492 (the first work to systematically lay out the grammatical rules of Spanish and in fact any modern European language) and Gloria Anzaldúa's seminal work of bilingual, autobiographical cultural criticism, Borderlands/La Frontera (which celebrates the creative dissolution of the limit between English and Spanish). Both of these texts, whether they preserve traditional language usage or diverge from it, represent political responses to language as a constantly changing entity.

3. A fascinating exploration of Spanish foreign policy and economic practices in the Philippines before 1868 can be found in Josep Fradera's Filipinas, la colonia más peculiar: la hacienda pública en la definición de la politica colonial, 1762-1868 (1999). For information on slavery in the Philippines and Philippine slavery in Mexico, see Tatiana Seijas's Asian Slaves in Colonial Mexico: From Chinos to Indians (2014).

4. Before the Latin American wars of independence, Spain's center of colonial government over the Philippines was in Mexico. The difficulty and length of the journey between Spain and the Philippines, in a boat either around Cape Horn or the Cape of Good Hope, made this displacement of imperial administration necessary. The 1869 opening of the Suez Canal allowed for much faster communication and travel between the Philippines and Spain, a crucial change given that Spain could not run its Philippine operation through Mexico after the war for independence broke out in Mexico in 1810 (Rafael, Promise of the Foreign 21).

5. Leonel-Antonio de la Cuesta calls this procedure of translation a "strange linguistic exercise" (51), and Pedro Pablo Rodríguez adds that Martí "still did not feel sure of his handle on English" and that The Hour did not yet employ a Spanish-to-English translator (9).

6. Mañach says that these were "published without correction, in Martís own English, loaded and strange, these impressions 'of a Fresh Spaniard' must have seemed to The Hour's readers shockingly lacking of the usual timidity and flattery of the recently arrived foreigners" (152). Esther Allen adds, "Several months into his work for Dana, Martí seems to have decided to try his hand at writing in English for a three-part series titled, "Impressions of America by a Very Fresh Spaniard.” Its markedly eccentric prose includes a number of grammatical and spelling mistakes that make it rather unlike the polished translations from the 
French previously published in The Hour. These errors alone indicate, to my mind, that this cannot simply be a poor translation (as Carlos Ripoll has maintained), but must be Martí's own often flawed but nevertheless spirited and forceful English which the editors and typesetters of The Hour decided to reproduce verbatim" (Allen 34).

7. As seen in his use of the term "America" without the accent mark over the "e," Martí has yet to find or establish an América that he can call his own. The term here refers to a cultural group to which Martí does not belong and that he deems is in need of correction. This correction occurs both in his prescriptions about the culture and social structures of "Nuestra América," and in the graphical transformation of the term represented by the accent above the "e."

8. The 1963 version of Martí's collected works emphasizes the ambiguity between impertinence and having recently arrived in the US using "fresco," while the 2003 version of Martí’s “Obras Completas” opts for less ambiguity, translating "very fresh" to "recién llegado."”

9. This is especially evident in Martí's 1881 article published in La Pluma of Bogotà, "Coney Island." In this chronicle, Martí expresses a great deal of anxiety toward the technological prowess and cultural crises of life in New York, repeatedly comparing what "they" do to what "we do." For example, there is "Aquellas gentes comen cantidad; nosotros clase," or "These people eat quantity; we, class" (Escenas norteamericanas 88, translation by Allen Selected Writings 93).

10. This "H" of "Heneral" is not an error, either. In 1890, José Rizal and other Filipino "Ilustrados" thought of and developed an insurgent orthography for writing Spanish in a particularly Filipino way. This included switching "G's" for "H's" and "C's" for "K's," among other adjustments. This can be inscribed in a transoceanic movement of polemical linguistics including debates in the Caribbean about substratum of Taíno languages in Caribbean Spanish and investigations into the supposedly Sanskrit roots of Tagalog, realized by nationalist linguists who looked to establish older and richer cultural patrimonies for the Philippines that sidestepped the classical traditions. Megan Thomas writes about this phenomenon at length in the fourth chapter of her book, Orientalists, Propagandists, and Ilustrados Filipino Scholarship and the End of Spanish Colonialism (2012), called 'Is 'K' a Foreign Agent? Philology as Anti-Colonial Politics.'

11. The contemporary term of feminist discourse for this interaction would be "mansplaining."

12. In fact, Luna systematically structures his reflections on the future of his country within a male-centric, sentimental framework, embodied most clearly in his autobiographical short story "Un beso en Filipinas" and in his performative fencing challenges of Spanish critics and fellow Filipino Ilustrados in Spain. 
13. In order to maintain the clarity of my analysis of the word "banca," I kept the word in Tagalog as Luna had in his text in Spanish. Fores-Ganzon translated it to "boat."

14. This can be seen when Barcelona journalist Mir Deas writes a scathing review of Antonio Luna's "Impresiones madrileñas," in which he confuses Antonio for his brother, the painter, Juan Luna, before proceeding to misspell Antonio's nom de plume, writing "Taga Iloc" which makes no sense in Tagalog, as opposed to the multiple senses that the penname contains.

15. One instance of Luna's rejection occurs with the young Madrileña's "Ahh..." One instance of Martí's rejection occurs when he tries to help an elderly lady who has fallen on the train. She initially acts as though she will accept his help, but when she recognizes him as a foreigner (it is not indicated whether this is a visual or audio form of recognition) she rejects his help and yells, "By the hand, no!"

16. While a chapter of Gloria Anzaldúa's Borderlands/La Frontera which explores the in-between linguistic condition of border dwellers, is titled "How to tame a wild tongue," Martí's gesture here could be described through an inversion of such a title: How to wild a tame tongue.

17. One of the chief literary critics of modernismo is Federico de Onís. Reflecting on Onís's writings, Alfonso García Morales says that "in Spanish America, modernism was the beginning of a truly independent literature" (494). Onís insists that modernismo isn't a strictly defined "school," nor is it a simple case of "afrancesamiento" or Frenchifying. Modernismo is a Hispanic response to a universal crisis of spirit and letters, in which writers such as Rubén Darío and José Martí dismantled traditions of romanticism in the Americas, seeking new forms of poetic symbols and meters. Modernismo sought to connect Latin American poetry with classical traditions of Rome and Greece, in large part as a rejection of North American forms of economic domination (495-496).

18. This reading of versified prose in "Impressions of America by a Very Fresh Spaniard” dialogues with the interpretive strategies of Julio Ramos's critique of Martí’s “El puente de Brooklyn” (1883). Martís prose assumes a rhythm and energy that does not mirror the content of the phrases. Ramos asserts that Martís versification is a complex form of engagement with modernity. Martí aims not only to represent the terms, tones, and measurements of modernity through an exposition of the Brooklyn Bridge's structural specifications and construction. He also struggles with these forms of modernity by stylizing them, using the form of the writing to engage not passively with the content. Ramos deems Martís writing purposefully difficult-its referential imperative is almost "illegible"-but that this difficulty registers a clash between codes and languages, between epochs and cultures, between the "strong" signs of modernity and Martî's defiant stylized response to them (Ramos 213). 
19. Through this complex proximity between culture and destructive nature, Martí begins to sketch a poetic and political framework that comes to fruition in later writings. In "Impressions," there are hints of the energy and versification behind his modernist poetics of Ismaelillo and Versos sencillos as well as his critiques of US modernity in chronicles such as "Coney Island" and "El puente de Brooklyn." There are indications of his exploration of the democratizing force of destructive nature as made explicit in his 1886 chronicle, "El terremoto de Charleston." Additionally, translation has been explored in Martí as a key to accessing world literature, especially in his 1882 chronicle on Oscar Wilde. In "Impressions," however, Martí uses translation to engage with the US but also to distance himself from the United States' expanding cult of industrialism. Martí affirms his cultural authority and plants the seed of radical separation between their America and "la nuestra." While in "Oscar Wilde," Martí demands that his readers use translation to get to know the literatures of all traditions and thus not to be oppressed by the tyranny of any one tradition, in "Nuestra América," Martí uses translation as a tool for America to get to know itself better, asserting that "Our own Greece is preferable to the Greece that is not ours" (291). Translation is a strategy for fighting back against imperialism and focusing inward, forging a uniquely American continental identity. Through translation, "Greece" becomes a concept that is abstractable from the historical and geographical situation of the country Greece. This potentially liberates the Americas from the need to justify their authority via European genealogies and patrimonies. And paradoxically, this gesture takes root in Martí's work through his assertion that he is none other than a "Fresh Spaniard." 


\section{Works Cited}

Allen, Esther. "He has not made himself known to me': José Martí, U.S. History, and the Question of Translation." Syncing the Americas: José Martí and the Shaping of National Identity. Bucknell UP, 2018.

“Análisis métrico I. La sílaba." Sobre poética. Blog. peripoietikes.hypotheses.org/590. Accessed on January 13, 2017.

Arendt, Hannah. 'What is authority? (1954)' pevpat-ugent.be/wpcontent/ uploads/2016/09 /H-Arendt-what-is-authority.pdf. Accessed on September 13, 2017.

"Banca." Diccionario de la Real Academia Española. dle.rae.es/?id=4wPQky6. Accessed on February 4, 2017.

Chandler, James A. "Spain and Her Moroccan Protectorate 1898 - 1927." Journal of Contemporary History. vol. 10, no. 2, April 1975, pp. 301-322.

Constantino, Renato and Leticia. A History of the Philippines: From the Spanish Colonization to the Second World War. Monthly Review Press, 1975.

Cuesta, Leonel Antonio de la. Martí, traductor. Cátedra de Poética Fray Luis de León, 1996.

de Onís, Federico. Antología de la Poesía Española e Hispanoamericana. Las Americas Publishing Co, 1961.

Ferrer, Ada. Insurgent Cuba: Race, Nation and Revolution, 1868-1898. U of North Carolina P, 1999.

Fores Ganzon, Guadalupe, translator. La Solidaridad: Quincenario Democrático, 1 (1889).

Fradera, Josep M. Colonias para después de un imperio. Edicions Bellaterra, 2005.

García, Gervasio L. "Estudio Introductorio: Historiar bajo censura, La primera historia puertorriqueña." Historia Geográfica, Civil y Natural de la Isla de San Juan Bautista de Puerto Rico. By Iñigo Abbad y Lasierra. Edited by José Julián de Acosta y Calvo, Ediciones Doce Calles, 2002.

García Morales, Alfonso. "Federico de Onís y el concepto de Modernismo: Una revisión.” Revista Iberoamericana, vol. 44, no. 184-5, July-December 1998.

Hagimoto, Koichi. Between Empires: Martí, Rizal, and the Intercolonial Alliance.

Palgrave Macmillan, 2013.

Jose, Vivencio R. The rise and fall of Antonio Luna. U of the Philippines P, 1972.

Kirk, John M. "José Martí and the United States: A Further Interpretation." Journal of Latin American Studies, vol. 2, no. 9, pp. 275-90.

Luna, Antonio. "Impresiones madrileñas de un filipino." La Solidaridad: Quincenario Democrático, 1, 1889.

Luna, Antonio. “Sangre torera." La Solidaridad: Quincenario Democrático, 1, 1889.

Mañach, Jorge. Martí, el apóstol. Las Americas Publishing Co, 1963. 
Martí, José. Selected Writings. Translated by Esther Allen, Penguin, 2002. Escenas norteamericanas y otros textos. Ediciones Corregidor, 2010.

Pratt, Mary Louise. Imperial Eyes: Travel Writing and Transculturation. Routledge, 1992.

Rafael, Vicente. Contracting Colonialism: Translation and Christian Conversion in Tagalog Society under Early Spanish Rule. Duke UP, 1988.

. The Promise of the Foreign: Nationalism and the Technics of Translation in the Spanish Philippines. Duke UP, 2005.

Ramos, Julio. Desencuentros de la modernidad en América Latina: Literature y politica en el siglo XIX. Editorial Cuarto Propio; Ediciones Callejón, 2003.

Rancière, Jacques. The Politics of Aesthetics. Continuum, 2006.

Rodríguez, Pedro Pablo. “Nota editorial.” José Martí. Obras Completas: Edición Crítica, Tomo 7 1880-1881. Centro de Estudios Martianos, 2003.

Rotker, Susana. Prologue. Crónicas, by José Martí. Edited by Susana Rotker. Debate, 2006.

Sánchez Gómez, Luis Ángel. Un imperio en la vitrina: El colonialismo español en el Pacífico y la Exposición General de las Islas Filipinas de 1887. Consejo Superior de Investigaciones Científicas, 2003.

Schmidt-Nowara, Christopher. The Conquest of History: Spanish Colonialism and National Histories in the Nineteenth Century. U of Pittsburgh P, 2006. . Empire and Antislavery: Spain, Puerto Rico and Cuba 1833-1874. U of Pittsburgh P, 1999.

Schnirmajer, Ariela. Introduction. Escenas norteamericanas y otros textos. Ediciones Corregidor, 2010.

Schumacher, S.J., John N. The Propaganda Movement: 1880-1895: The Creation of a Filipino Consciousness, The Making of the Revolution. Ateneo de Manila UP, 1997.

Seijas, Tatiana. Asian Slaves in Colonial Mexico: From Chinos to Indians. Cambridge UP, 2014.

Sommer, Doris. Proceed with Caution: When Engaged by Minority Writing in the Americas. Harvard UP, 1999.

Thomas, Megan C. Orientalists, Propagandists and Ilustrados: Filipino Scholarship and the End of Spanish Colonialism. U of Minnesota P, 2012. 